\title{
Epistemic Investigation into Jeremy Bentham's Theory of Capital Punishment: Implications on Nigeria Situation
}

\author{
Raphael Olisa Maduabuchi, Stephen Chijioke Chukwujekwu, Rita Zubechukwu Madu \\ Department of Philosophy, Chukwuemeka Odumegwu Ojukwu University, Igbariam Campus, Anambra State, Nigeria \\ Email: ro.maduabuchi@coou.edu.ng,cs.chukwujekwu@coou.edu.ng, zubehappy037@gmail.com
}

How to cite this paper: Maduabuchi, R. O., Chukwujekwu, S. C., \& Madu, R. Z. (2021). Epistemic Investigation into Jeremy Bentham's Theory of Capital Punishment: Implications on Nigeria Situation. Open Journal of Philosophy, 11, 75-84.

https://doi.org/10.4236/ojpp.2021.111007

Received: April 22, 2020

Accepted: January 29, 2021

Published: February 1, 2021

Copyright $\odot 2021$ by author(s) and Scientific Research Publishing Inc. This work is licensed under the Creative Commons Attribution International License (CC BY 4.0).

http://creativecommons.org/licenses/by/4.0/

\begin{abstract}
This work tends to examine capital punishment in Jeremy Bentham's utilitarianism and its application to Nigeria situation. Capital punishment is a controversial issue in many parts of the globe. The high incidence of crime in Nigeria, Africa and other parts of the world calls for a stringent measure to curb this menace in society. The proponents of capital punishment are of the view that capital punishment helps to deter or prevent crimes. But, in what sense can capital punishment serve as an effective deterrent? On the other hand, the opponents of capital punishment conceive that capital punishment promotes the culture of violence in society, which violates human dignity and right to life. This study made use of textual analysis. Data collected from books and journals were analysed using analytical, expository and critical methods. Jeremy Bentham seeks to resolve this dilemma by positing that capital punishment can be justified only if it can contribute to a significant increase in the happiness of others.
\end{abstract}

\section{Keywords}

Capital, Punishment, Utilitarianism, Crime, Culture, Nigeria, Violence and Happiness

\section{Introduction}

Social contract is made for the common good of the society. Common good is the basis of formation of any civil society. Law is enacted to maintain peace and order which promote the common good of the society. But, the high incidence of crime in Nigeria and other parts of the world militates against well being of the society. It calls for a stern measure to control this problem. This is sequel to the 
fact that law is not an empty command. It is backed with threat or punishment to enforce its compliance.

There are degrees of punishment. Every crime does not deserve the same punishment. Capital crimes such as armed robbery, kidnapping, arson, murder, drug trafficking, treason, terrorism, treachery, coup d'état, mutiny and so on are punishable by capital punishment. It is important at this point to clarify the basic concepts that are associated with this work.

\section{Conceptual Clarification of Basic Terms}

The key terms that are associated with this work are: capital punishment and utilitarianism. The term capital punishment is derived from a Latin word "capitalis" which means "the heading". Literally, capital punishment denotes "beheading". It is a legal process whereby a person is put to death by the state as a punishment for crime. According to Hood (2019), capital punishment is also called death penalty. It is execution of an offender sentenced to death after conviction by a court of law of a criminal offence.

There are many definitions of capital punishment. Capital punishment or death penalty is defined as "an institutionalized practice designed to result in deliberately executing persons in response to actual or supposed misconduct and following an authorized, rule-governed process to conclude that the person is responsible for violating norms that warrant execution" (Hoag, n.d). Death sentence has been in practice from time immemorial. It is carried out through so many means such as guillotine, hanging, lethal injection, electrocution, firing squad and so on. Sometimes, the execution is not carried out immediately. Their names are included in the death row for some period while cases are appealed. An appeal can be made for life imprisonment in some cases of lesser offences.

On the other hand, utilitarianism is derived from the root word "utility". Eboh (1995) conceived that utilitarianism is an ethical principle which holds that the morality of an act consists essentially of its utility as means for attainment of the happiness of man, happiness in most cases being considered temporal. In other words, it conceives utility as the standard of morality. Utility means happiness or pleasure for utilitarians. For them, pleasure is the motivation of all human action. In this sense, if you want to know an action that is good or bad, find out whether it useful or not. It is only action that is useful is good and vice versa.

In general term, utilitarianism is a philosophical principle. As a philosophical principle, utilitarianism is the principle of the greatest good for the greatest number of people. In this work, capital punishment will be conceived in the light of Jeremy Bentham's utilitarian principle.

\section{Theoretical Framework}

This work is anchored on utilitarian theory of capital punishment. The chief proponents of utilitarianism were John Stuart Mill and Jeremy Bentham. Contrary to retributive theory which conceives capital punishment as an act of re- 
tribution, utilitarian perspective is another philosophical approach to capital punishment which conceives that capital punishment serves as a deterrent for crime.

In his speech on capital punishment, John Stuart Mill rejects various arguments against capital punishment and upholds that capital punishment is a superior deterrent to the alternative of life imprisonment with hard labor. His view was based on the fundamental proposition that capital punishment has a significant deterrent effect on criminal behavior. Hence, he envisages that the deterrent effect of capital punishment is achieved by its appearance of severity. Its severe form of punishment would effectively deter murder. According to Robson, \& Kinzer (1988), John Stuart Mill expresses thus with respect to capital punishment:

I defend this penalty, when confined to atrocious cases, on the very ground on which it was commonly attacked on that of humanity to the criminal; as beyond comparison the least cruel mode in which it is possible adequately to deter from (p. 267).

Mill rejects various forms of argument against capital punishment, especially the claim that it is incompatible with respect for human life. Against the argument of capital punishment on the basis of miscarriage of justice on Innocent victim, Mill infers that capital punishment necessarily renders the courts of justice more scrupulous in requiring evidence of guilt in order to avert this malaise. Therefore, he recommends capital punishment strongly for aggravated murder. This work will examine Jeremy Bentham's utilitarian theory of capital punishment and it implications on Nigeria situation.

\section{Jeremy Bentham's Theory of Capital Punishment}

Jeremy Bentham was a social reformer and founder of utilitarianism. Jeremy Bentham theory of capital punishment stems from his conception of punishment. For him, punishment is evil in itself because it causes pain or suffering. But, punishment can be permitted on utilitarian ground if it is used to prevent or exclude some greater pain (Bentham, 2000: p. 134). In this regard, punishment is meant to prevent crime or offense in order to secure the greatest good for the greatest number.

It is against utilitarian principle to punish someone in order to exact vengeance or retribution. Bentham (2000) goes further to denote what punishment should consist of. Hence, he delineates the proportion between punishment and offenses in the following rules:

1) The value of punishment must not less in any case than what is sufficient to outweigh that of the profit of the offence. 2) The greater the mischief of the offense, the greater is the expense which it may be worthwhile to be at, in the way of punishment. 3) Where two offences come in competition, the punishment for the greater offence must be sufficient to induce a man to prefer the less. 4) The punishment should be adjusted in such manner to 
each particular offence, that every part of the mischief there may be a motive to restrain the offender from giving birth to it. 5) The punishment ought in no case to be more than what is necessary to bring it into conformity with the rules here given. 6) That the quantity actually indicted each individual offender nay correspond to the quantity intended for similar offender in general, the several circumstances influencing sensibility ought always to be taken into account. 7) To enable the value of the punishment to outweigh that of the profit of the offense, it must be increased, in point of magnitude, in proportion as it falls short in point of certainty (pp. 141-142).

Bentham goes further to stress that punishment is subservient to reformatory in proportion to its quantity. Hence, he believes that "the greater the punishment a man has experienced, the stronger is the tendency it has to create in him an aversion towards the offence which was the cause of it" (Bentham, 2000: p. 152). Thus, he envisages that punishment for offenses originating from the motive of ill-will has the strongest reforming tendency. For instance, the punishment for offenses which consist in an obstinate refusal to obey the law, which is nurtured by his resentment against those who have an interest in forcing him to compliance, seems to be confinement to spare diet. He further suggests penal labour for other offences like theft, embezzlement, and every species of defraudment.

Although Jeremy Bentham is not an ardent proponent of capital punishment, he postulates that grievous offenses which defy reformation or disabling efficacy in the sense that it has no certain way of disabling a man from doing mischief either to himself or others is to be punished by death. Other people included in this category are the competitors for the sovereignty and leaders of the factions in civil wars, whose existence is enough to keep a whole nation in a flame (Bentham, 2000: p. 153).

\section{Morality of Capital Punishment}

Capital punishment is a controversial issue in philosophy. Kant conceives that the morality of an act depends on having the right motive. He propagates for the law of retribution, where capital punishment is used to exact vengeance for evil offence like murder. Immanuel Kant is somehow right by saying that offenders must suffer a punishment equal to the victim's suffering because the law of retribution can serve to deter people from committing heinous crime like murder.

On the other hand, Jeremy Bentham argues against using capital punishment as an act of retribution or vengeance. For him, it is morally offensive to use capital punishment to avenge evil acts because it tends to increase pain and suffering. It is a morally wrong as the crime it is intending to punish for two wrongs do not make right (Thompson, 2016: pp. 32-33). Thus, Bentham argues that its use should be greatly limited.

However, Bentham was a partial opponent of capital punishment. He conceives that capital punishment is going to increase the suffering of the criminal 
but it can be justified only if it will promote the happiness of others in the society. Criminal offences like armed robbery and murder will tend to bring pain in the society by creating the atmosphere of fear and insecurity. Thompson (2016) envisages that capital punishment is justified if it deters crimes or reform criminals so as to create a safer and happier society. By so doing, Bentham saw a slight value in capital punishment.

It is wrong for Bentham to think that capital punishment could be used for rehabilitation or reformation of criminals since when one is dead nothing can be done. Death marks the end of one's existence. To curb this anomaly, Bentham envisages that capital punishment should be used only for the crime for which it could be shown to be an effective deterrent.

Contrary to this viewpoint, the existentialists conceive life as the ultimate value of human existence. Hence, Jean Paul Sartre postulates that existence precedes essence. The question is: are societal values more important than human life? Some moralists are of the view that capital punishment is below human dignity. As a result, they recommend life imprisonment with hard labour as a substitute to capital punishment. In which ever be the case, capital punishment is still problematic in this contemporary era. Even the moralists that advocate for capital punishment, punishment by death penalty has peculiar challenges associated with it.

\section{Implications of Jeremy Bentham's Conception of Capital Punishment on Nigeria Situation}

Jeremy Bentham shares the utilitarian principle which conceives that morality of human act is in its outcome or consequence. He conceives that capital punishment is justified if it will promote the happiness of the greatest good for the greatest number of people in the society. In his own view, capital punishment is good if it is used to deter crime or reform criminal. Jeremy Bentham's concept of capital punishment, therefore, has great relevant implications on Nigeria socio-political situation.

Nigerian society is bedeviled with security challenges ranging from kidnapping, ritual killings, armed robbery, herds men attack and Boko Haram insurgency. Bentham rightly conceives that competitors for the sovereignty and leaders of terrorist organizations like Boko Haram and Fulani herdsmen whose existence in Nigeria is likely to put the whole Nigeria into a flame ought to be executed in order to ensure peaceful co-existence of individuals in Nigeria. This is in line with Jeremy Bentham's idea of promoting happiness for the greatest number of people.

Government has essential role to play in legislation of law to ensure pleasure and happiness of the community. Capital crimes threaten peace and order in the society. In some countries, government has passed capital punishment into bill while other countries seem to adopt life imprisonment in place of capital punishment. Although the Legislatives make laws and pass laws into bill, the duty of judiciary is to interpret and apply the existing law to individual cases in the 
court of law. It is important at this juncture to examine the notion of capital punishment in Nigeria criminal law.

\subsection{Capital Punishment in Nigeria Criminal Justice System}

Capital punishment is a controversial issue not only in philosophy but global world at large. It is adopted in Nigeria's criminal justice as punishment for capital crime like willful murder. One of the fundamental human rights is a right to life. According to section 33(1) of 1999 Constitution of Federal Republic of Nigeria (n.d), the basic fundamental human rights as thus:

Every person has a right to life, and no one shall be deprived intentionally of his life, save in execution of the sentence of a court in respect of a criminal offence of which he has been found guilty in Nigeria (p. 14).

Capital punishment as it is evidence in Nigeria constitution is geared to protect the fundamental right to life. The execution is carried out by court sentence against a person who is found guilty of criminal offence. It is only the state that has right to deprive any member of its citizen the right to live. No one has the right to deprive his fellow human being of his/her fundamental right to life. On the other hand, there may be an occasion where a person will not be held responsible for killing as in the case of self defence. There are other occasions where a person is not held liable for killing as it is stipulated in section 33(2) of 1999 Constitution of Federal Republic of Nigeria (n.d):

A person shall not be regarded as having been deprived of his life in contravention of this section, if he dies as a result of the use, to such extent and in such circumstances as are permitted by law, of such force as is reasonably necessary: 1) for the defence of any person from unlawful violence or for the defence of property: 2) in order to effect a lawful arrest or to prevent the escape of a person lawfully detained; or 3) for the purpose of suppressing a riot, insurrection or mutiny (p. 14).

Death sentence and death accruing from these circumstances are heroic because it is geared to serve for the good interest of the State. Amnesty International recorded that Nigeria ranked second in the world after China on death penalty in 2016 (Onyeji, 2017). However, some people advocate that capital punishment should be abolished in Nigeria on the basis of its condemnation in the international community. The international community has abolished capital punishment on the ground that it is a violation of fundamental human right and human dignity. But, the position of the law on fundamental human right and death sentence in Nigeria are different. Nigeria Constitution, which is binding on all Nigerians, regards death penalty as a valid exception to the right of life (Peters, 2017).

\subsection{Capital Offences in Nigeria Criminal Law}

Nigeria criminal law classifies offences into three main categories such as: simple 
offences, misdemeanors and felony. Simple offences are not grievous offences. All offences apart from misdemeanor and felony are simple offence. Misdemeanor, on the other hand, is offences the law declared to be punishable for not less than six months but less than three year. Whereas, felony is punishment without proof of previous conviction with death or imprisonment for more than three years or more (Peters, 2017). Capital offenses are grievous offences that are punishable by death penalty.

Capital offences punishable by death penalty are contained in the criminal code and penal code. Offences that are punishable by death under criminal code are: treason, treachery, murder, armed robbery. In the same vein, capital offences punishable by death under penal code are: homicide, "military offences like Dereliction of duty, Misconduct in action and Mutiny as well as Adultery, Apostasy, Sodomy and so on" (Peters, 2017). The criminal code is used in the Southern Nigeria while penal code is adopted in Northern Nigeria.

Another offence that is punishable by death in Nigeria is kidnapping. In the other parts of the world, drug trafficking, arson, terrorism and so on.

\subsection{Methods of Execution of Capital Punishment}

There are different methods of execution of death penalty. But, the methods of execution sometimes differ from one place to another. In Nigeria for instance, the two major methods of execution of death sentence are thus: hanging and shooting or firing squad. Death by hanging is a common mode of execution of death sentence in Nigeria. The culprit is hanged with a rope to facilitate death. Recently, a yahoo boy who killed the former Ondo deputy governor's daughter for money ritual was sentenced to death by hanging on $27^{\text {th }}$ of March 2019.

The other form of execution is used mainly during military regime in Nigeria. In 1990s, the executions by firing squad were public event, attended by large crowd. At times, the execution is broadcast on television in order to deter people from committing similar offences (Maduabuchi, 2016). Death by shooting or firing squad is still in vogue in most recent time. For instance, on $17^{\text {th }}$ December 2014, about fifty-four soldiers in Nigeria were sentenced to death by firing squad after they were found guilty of mutiny.

In other parts of the globe like Asia, Europe and America, other forms of executions are adopted like lethal injection, electrocution, gassing, guillotine and so on. Lethal injection is common in United State of America. The culprits of capital crimes are injected with poisonous substance to die. Electrocution is a cruel form of execution where "death is brought upon the convict by cardiac arrest and respiratory paralysis; electric current is passed into the convict's body until he gives up the ghost" (Ebe, n.d). Gassing is a method where the convict is made to inhale poisonous gas like cyanide in a gas chamber. Adolf Hitler killed six million Jews during the Second World War through this means. Guillotine is another form of execution used mainly in Saudi Arabia and other Islamic countries where a machine is used to cut off the head of the condemned convict. This 
method is also known as beheading or decapitation.

\section{Critical Evaluation of Capital Punishment in Jeremy Bentham's Utilitarianism}

Jeremy Bentham is not an ardent proponent of capital punishment. His view on capital punishment is geared to deter crimes in order to promote the greatest good for the greatest number of people. However, there are some problems or challenges associated with the utilitarian conception of capital punishment.

In the first instance, Jeremy Bentham's theory of capital punishment considers only one aspect of capital punishment as a means of deterrence or preventing crime. There is the need for other raminifications of death penalty. Retributive approach is equally important because it considers the amount of punishment appropriate for a particular offence. One of the fundamental human rights is right to life. When someone violates this right to take away the life of his/her fellow human being, the only punishment that can appease this crime is death sentence. Immanuel Kant is right by conceiving that murder is punishable by death sentence. This act will serve to deter others from committing the same crime. Thus, utilitarian and retributive principles of capital punishment serve to complement each other.

Although the utilitarians conceive that capital punishment serve to deter and prevent crimes, the opponents of capital punishment criticize this view by considering the brutalizing effects of capital punishment on the society. Hence, Cesare Beccaire criticizes the cruelty of death sentence and advocates for life imprisonment as a sufficient deterrent for the most serious crimes. In his view, death sentence is disproportionately severe which cannot serve as an effective deterrent for crimes (Thompson, 2016: pp. 29-30). Contrary to this viewpoint, the severity of capital punishment is good enough to deter the grievous crimes in the society. Capital punishment can serve as an effective deterrent for serious crimes but there are some problems associated with capital punishment.

One of the problems associated with capital punishment is that capital punishment can be mistakenly carried out on innocent victims. Many people have been proclaimed to be innocent long after the execution. This radical form of execution is carried out in some cases against the poor and people from low economic situation or background.

Capital punishment can serve as an effective deterrent of serious crimes in the society. It prevents other people in the society from committing crimes as Jeremy Bentham and other utilitarian philosophers conceive but it cannot reform criminals after death. Thus, it does not give room for criminals to repent. Life imprisonment, on the other hand, has its own peculiar problem which may promote laxity. When people are not punished effectively for the crimes they committed, it tend to encourage others to commit the same crime, thereby, promoting disharmony in the society. The debate between the proponents and opponents of capital punishment is a philosophical problem which is still en- 
demic in this contemporary period.

Not withstanding the contentions of Jeremy Bentham's utilitarian theory of capital punishment, capital punishment in Bentham utilitarianism is still relevant in this contemporary period to deter or prevent crimes in order to promote the greatest happiness of people in the society. His theory of capital punishment has great implications on Nigeria socio-economic situation. Nigeria contemporary society has many security challenges ranging from terrorism, Boko Haram insurgency, herds men attack, armed robbery, kidnapping to mention but a few. Jeremy Bentham's theory of Capital punishment is very important in Nigeria legal system to deter and curb these crises that threatens the peaceful co-existence of individuals in the society.

Jeremy Bentham's theory of capital punishment calls for reforms in Nigeria prison services and the treatment of prisoners. The state of prisoners in many Nigerian prisons and other parts of the world are below the level of human dignity. Sometimes, many prisoners die before their trial as a result of starvation, unconducive environment, diseases, suffocation and other unfavourable circumstances that militate against human well being. Prisons ought to be conducive environment for reformation of criminals. There is the need to establish entrepreneurial programmes to enable the prisoners to acquire skills for useful living that will make them start a new life in the society when they are acquitted or discharged.

\section{Conclusion}

This work has examined the morality of capital punishment in Jeremy Bentham's utilitarianism and its implications on Nigeria socio-political situation. Bentham's theory of capital punishment serves to promote the social contract for the common good of the society. A good implementation of capital punishment in the light Jeremy Bentham's utilitarianism will help to promote peace and unity of Nigeria and other parts of the globe in this contemporary period. Thus, Jeremy Bentham had established a great legacy that will promote the greatest good for the greatest number of people in this contemporary period.

\section{Conflicts of Interest}

The authors declare no conflicts of interest regarding the publication of this paper.

\section{References}

Bentham, J. (2000). An Introduction to the Principles of Morals and Legislation (pp. 134). Kitchener: Batoche Books.

Constitution of Federal Republic of Nigeria (n.d) Constitution of the Federal Republic of Nigeria 1999. https://www.wipo.int/edocs/lexdocs/laws/en/ng/ng014en.pdf

Ebe, T. (n.d). Capital Punishment in Nigeria Criminal Law, A Research Project Submitted Faculty of Law, University of Uyo, Uyo, Akwa Ibom State, Nigeria. http://www.coursehero.com/file/CAPITAL-PUNISHMENT-I\%E2\%80\%A6 
Eboh, B. O. (1995). Living Issues in Ethics (pp. 45). Nsukka: Afro-Orbis Publishing Co. Ltd.

Hoag, R. (n.d). Internet Encyclopedia of Philosophy. https://www.iep.utm.edu/cap-puni/

Hood, R. (2019). Capital Punishment Law in Encyclopedia Britannica. http://www.britannica.com/topic/capital-punishment

Maduabuchi, O. R. (2016). Elements of Professional Ethics (pp. 66). Enugu: Faba Communications.

Onyeji, E. (2017). Death Sentences: Nigeria Ranks Second in the World after China-Amnesty International.

https://www.premiumtimesng.com/news/top-news/228669-death-sentences-nigeria-ra nks-second-world-china-amnesty-international.html

Peters, I. (2017). Argument on the Abolishment of Death Sentence in Nigeria. A Juxtaposition.

https://dnllegalandstyle.com/2017/arguments-abolishment-death-sentence-nigeria-juxt aposition/

Robson, J. M., \& Kinzer, B. L. (1988). Public and Parliamentary Speeches by John Stuart Mill (November 1850-November 1868) (pp. 267). Abingdon-on-Thames: Routledge.

Thompson, B. E. (2016). The Greenhaven Encyclopedia of Capital Punishment (p.33). New York, NY: Greenhaven Press. 